\title{
Audit Firm Rotation and Audit Report Lag in Nigeria
}

\author{
Austine, O. Enofe, Ph.D., Chijioke, O. Mgbame, Ph.D., Henry, S. Abadua \\ Department of Accounting, Faculty of Management Sciences, University of Benin, Benin City, Nigeria.
}

\begin{abstract}
Audit firm rotation and audit report lag has been a topical issue to regulators, investors, practitioners and the public at large. Hence, this study is designed to determine the relationship between audit firm rotation and audit report lag in Nigeria. Secondary data gathered from the 2011 annual reports of fifty (50) randomly selected companies, quoted on the floor of the Nigerian Stock Exchange (NSE) were employed in the study. The Ordinary Least Square technique (OLS) was used in the analysis of the relationship between the dependent and independent variables. The study reveals that audit fees, year-end and audit firm type all have positive relationship with audit report lag. The research also establishes that audit firm rotation and company size have a negative insignificant relationship with audit report lag.
\end{abstract}

Keywords: Audit Firm Rotation, Audit Report Lag, Timeliness

\section{Introduction}

Timeliness has been recognized in the past few decades as one of the qualitative characteristics of financial reports (AICPA, 1973; FASB, 1979). The Financial Accounting Standard Board (FASB) has pointed it out as one of the quality of accounting information from the viewpoint of decision usefulness. According to the FASB's conceptual framework (SFAC) No. 2, there are four criteria that a financial report must possess in order to be useful for users' decision-making. The four criteria include relevance, verifiability, free from bias and quantifiable. For annual report to be relevant the provision of information must have predictive or feedback value and that information should be provided in a timely manner. Past experience in the capital market shows that timeliness critically affects investor's chances of being defrauded, the degree of uncertainty on investment evaluation, as well as the expected payoff. More precisely, the importance of timely disclosures stems from the equality of information access among investors, without which other well 'informed' investors may use their private information to exploit the less 'informed' investors. Therefore, it is not surprising to see policy makers expressing concern about the timeliness of disclosures (Financial Accounting Standard Board [FASB], 1980; Security and Exchange Commission [SEC], 2002). One of such concerns is the issue of timeliness and audit firm rotation.

With a series of recent accounting sandals since the Enron and WorldCom debacle, the proposal of mandatory audit rotation has been put back on the agenda (Sarbanes-Oxley Act, 2002; corporate law economic Reform program Act, 2004).

While mandatory audit firm rotation has already been implemented in such countries as Italy, Brazil, and Singapore, regulators in the U.S., UK, and Nigeria among others are still debating the issue of audit firm rotation although they have advocated and implemented audit partner rotation as a means to restore public confidence in corporate financial reporting due to fierce opposition. Furthermore, the seeming delay is based on the disagreement as to what effect the rotation of audit firm would have on timely reporting.

\section{Statement of the Research Problem}

There have been various observations and comments on audit firm rotation and audit report lag from various research groups and institutes. It is a topical issue amongst stakeholders and has been debated for over some decades now. Crusaders for audit firm rotation argue that audit quality diminishes with long audit tenure; that audit firm rotation will reduces familiarity threat, ensures auditors' independence, and provides a greater skepticism and a fresh perspective that may be lacking in long-standing auditor client relationships (Firth, Rui \&Wu, 2010; Hyeeso, 2004; Riuz-Barbadillo \& Gomez-Aguilar, 2002). Dopuch, King and Schwartz (2001) noted that the longer an audit firm retains a client, the higher the potential of impairing auditors' independence.

What their argument suggests is that the longer an auditor is engaged by a client, the higher the probability for a decline in audit quality and this decline in quality will negate any associated benefit of timely reporting if any. Furthermore, Onwuchekwa, Erah, and Izedonmi (2012) argue that audit rotation would reduce the closeness auditors may have with managers, which will affect their independence and also may help to prevent corporate collapses. However, the opponents of mandatory audit firm rotation argue that longer auditclient relationships improve audit quality because the auditor acquires client specific knowledge over time. The implication of these according to Onwuchekwa et al (2012) is that audit quality is lower in the early years of the audit and improves with the length of audit tenure due to the reduction in information unevenness between the 
auditor and the client. They also claim that increasing the frequency of audit changes will raise the frequency with which the start-up costs associated with first-year engagements are incurred and, consequently, increase total audit costs (Arrunada \& Paz-Ares, 1997; Chung, 2004; Francis, 2004; Johnson, Khurama \& Reynolds, 2002; Nagy, 2005). The implication of their argument is that as the firm continues the audit of a client, over time, they become familiar with the trouble spots and weaknesses in the accounting system, which invariable should help them give a timely report on the state of affairs of the financial condition and consequently improve audit quality. Furthermore, Onwuchekwa et al (2012) noted that the recent financial crisis in the banking sector in Nigeria is the pivotal rationale why the apex bank decided to ensure audit rotation is done every ten (10) years. However, the justification for this study lies in our argument that, why would the decision of the apex bank be restricted to the banking sector alone? Is it not possible that the mandatory rotation of audit firm will affect the timely reporting of audit since the new audit firm will have to treat the client as a new client and not a continuing client?

From the foregoing discussion, it is evident that the debate for audit firm rotation is far from settled as there are no overwhelming evidences to justify its compulsion or otherwise. Furthermore, in light of the corporate scandals in Nigeria, it is of immense importance to consider if audit firm rotation may or may not affect timely reporting. These questions and many more necessitated the initiation of a study on audit firm rotation and audit report lag in Nigeria. The following questions are worthy of answers:

1 To what extent does rotation of audit firm affect audit report lag?

2 What relationship exists between audit fees and audit report lag?

3 What is the effect of the size of the company on the audit report lag?

4 Does the type of audit firm have a positive relationship with audit report lag?

5 To what extent can year-end date affect the audit report lag?

\section{Objectives of the Study}

The objectives of this study are to evaluate if:

1 the rotation of audit firm will significantly affect audit report lag;

2 a positive relationship exist between audit fees and audit report lag;

3 the size of the company can affect the audit report lag;

4 the type of audit firm has a positive relationship with audit report lag; and

5 year-end dates significantly affect the audit report lag.

\section{Statement of Research Hypotheses}

The following hypotheses stated in their alternate form have been put forward for the purpose of this study

1 The rotation of audit firm significantly affect audit report lag.

2 A positive relationship exist between audit fees and audit report lag.

3 The size of the company affects the audit report lag.

4 The type of audit firm has a positive relationship with audit report lag.

5 Year-end dates significantly affect the audit report lag.

\section{Concept of Audit Report Lag (ARL)}

\section{Literature Review}

The term "audit report lag" has been used to denote the elapsed time between the close of a fiscal year and the end of audit fieldwork. The latter is normally the date on which substantive audit tests are completed and the auditor leaves the client's premises. It is typically connoted by the date the auditor append his signature on the audit report. Prior researchers such as Davies and Whittred (1980), Newton and Ashton (1989), Whittred (1980) and Williams and Dirsmith (1988) have considered the relationship that various factors might possibly have on audit lag. Some of the factors that have been investigated include: presence of accounting or disclosure issues such as extraordinary items, loss contingencies, uncertainty audit qualifications, sign of earnings, nature, size and complexity of client operations, controls and proportion of audit work after year end, presence of subsequent events, accounting changes and whether the audit firm tends to follow a structured audit approach (Davies \& Whittred, 1980; Whittred, 1980; Ashton et al., 1987; Williams \& Dirsmith, 1988; Newton \& Ashton, 1989; Ashton et al., 1989).

According to Penman (1984), it has been suggested that management has incentives to exercise discretion over the timeliness of reporting. In particular, it has been hypothesized in literature that bad news is released later than good news and empirical researchers such as Whittred and Zimmer (1984) and Kross and Schroeder (1984) strongly supports this contention. Givoly and Palmon (1982) noted that unevenness in the length of the annual audit is a factor that explains the unpredicted length in reporting delay. Ashton et al. (1987) also examined the relationship between audit report lag (ARL) and a set of explanatory variables. They 
examined 14 variables from 488 U.S. clients of Peat, Marwick, Mitchell \& Co. in 1981-82 and their sample included both public and nonpublic clients from six industries.

The variables were total revenues, firm complexity, industry classification, public/nonpublic status, month of fiscal year-end, quality of internal control, the relative mix of audit work performed at interim and final dates, the length of time the company had been a client of the auditor, two measures of profitability and the type of audit opinion issued. The observed results revealed that only five variables were significantly associated with the natural logarithm of audit delay-total revenues.

Ashton et al. (1987) in their analysis of company ownership found that audit delay was significantly shorter for public companies after controlling for other factors. The study also separately analyzed public and private companies to explore whether the explanatory variables were differentially related to the two subsamples. The results showed that the two subsamples were not similar. While company size significantly affected audit delay for private companies it was not associated with audit delay for public companies.

\section{Audit Report Lag (ARL) and Audit Firm Rotation}

Audit firm rotation is designed to overcome two problems that can occur if an organization hires the same audit firm year in and year out. The first problem is that there is a tendency for the audit firm to get too cozy with the management of the organization they are assigned to audit since personal and professional ties can easily impede auditors' independence. Secondly, audit rotation provides the opportunity for the organization to be examined with a fresh pair of eyes.

Though this second issue is subtle, it is still worth considering. Accountants are creatures of habits. Things are done the same way as they were last year and often in a very mechanical and non-critical manner.

Many audit procedures and test are normally mechanical and this makes it very easy not to view audit process from a sufficiently critical and analytical point of view; sometimes the most glaring internal control weaknesses can be overlooked simply because the auditors were not looking at the big picture but only concentrating on the minutia.

A change of auditor guarantees that the organization in its entirety will get a fresh look and glaring internal control problems that may have been over looked by the prior auditors may get picked up by the new ones.

\section{Audit Report Lag (ARL) and Control Variables}

An audit report lag or audit delay is a period from a company's year-end date to the audit report date. The determinants of Audit report lag (ARL) have long been a topic of academic interest.

Dyer and Mchugh (1975) undertook a study on 120 of Australian Annual Report between years of 1967 to 1971 . Their objective was to examine the relationship between corporate attributes and audit delay. Of the three (3) variables examined, only company size had a significant relationship with audit delay, others did not have any meaningful relationship between audit report lag. A plausible explanation may be that bigger companies have more resources to pay high fees and appoint good auditor in order to complete the report timely.

Furthermore, Davies and Whittred (1980) suggested that the only variable that should be considered significant in examination of the determinants of audit lag is company size because larger companies have the potentials to reduce uncertainty about performance of the share price and timely release of the audit report.

Ahmed (2003) carried out a study of the timeliness of corporate annual reporting in three countries, Bangladesh, India, and Pakistan. The variables of interest were company size, sign of earnings, company financial condition, audit firm size, and company year-end. He observed that profitability and corporate size are significant determinants of audit report lag in Pakistan.

Owusu-Ansah and Leventis (2006) carried out investigation for the factors that affect timely annual financial reporting practices of 95 non-financial companies listed on the Athens Stocks Exchange. They found out that the size of company and audit firm type (big-5 audit firms) significantly affected the audit report lag.

The deduction from this might be that aside the resources larger companies have at their disposal to ensure timely reports, the type of audit firm also matter and have a higher propensity to issue timely report because of the larger audit staff or expertize. Furthermore, Ahmed (2003) in his study of the determinants of audit lag discovered that profitability and corporate size are significant determinants of audit report lag in Pakistan alone. However, with respect to the other countries, the audit firm size was a significant determinant in India and Pakistan, but not in Bangladesh.

It has also been observed that companies with year-ends at peak audit seasons generally experience longer ARL. Companies that also receive qualified audit opinions have comparatively longer ARL. Ahmad and Kamaruddin (2003) in their examination of Malaysian public companies that were listed for the year 1996 to 2000 discovered that out of eight variables examined; only six of them were significant. Account year-end was one of the significant variables. The implication is that the fiscal year end of a company can also determine how 
timely the audit report is given. A prior assumption is that companies with fiscal year-end other than December seem to have timely report that those with December as their fiscal year.

\section{Methodology}

For the purpose of this study, secondary data has been gathered from the 2011 annual reports of fifty (50) randomly selected companies quoted on the floor of the Nigerian Stock Exchange (NSE). The Ordinary Least Square technique (OLS) was employed in the analysis of the relationship between the dependent and independent variables. Our choice of this technique is informed from the Gauss-Markov Theorem. The Eviews 7 software was used in estimating the model.

\section{Measurement of Variables and Model Specification}

The following variables are considered relevant in the building of the model for examining the relationship between audit firm rotation and audit lag. Consequently, the model as built by the researcher in its equation form is specified below.

AUDLAG $=\beta o+\beta 1$ AUDFMR $+\beta 2$ AUDFEES $+\beta 3$ AUDSIZE $+\beta 4$ COMSIZE $+\beta 5$ YEND + Ut $\ldots \ldots \ldots \ldots \ldots . . . . . . e q 1$

Where:

AUDLAG $=$ Audit lag

AUDFMR $=$ Audit Firm Rotation

AUDFEES $=$ Audit Fees

AUDSIZE $=$ Audit Firm Size

COMSIZE $=$ Company Size

YEND $=$ Fiscal Year End

Operationalization of Variables

\begin{tabular}{|l|l|l|l|}
\hline Variables & Proxy & Operationalization & Aprior Sign \\
\hline Audit Lag & AUDLAG & $\begin{array}{l}\text { Number of days between the fiscal year end and the } \\
\text { time the audit report is signed }\end{array}$ & \\
\hline Audit Firm Rotation & AUDFMR & $\begin{array}{l}\text { Assign "1" if the audit firm was switched between the } \\
\text { last three years prior to 2011, otherwise "0" }\end{array}$ & $+;-$ \\
\hline Audit Fees & AUDFEES & Amount paid for audit service & $+;-$ \\
\hline Audit Firm Type & AUDSIZE & Assign "1" if big four, otherwise "0" & - \\
\hline Company Size & COMSIZE & Log of total assets & $+;-$ \\
\hline Fiscal Year End & YEND & $\begin{array}{l}\text { Assign "1" if fiscal year end is December, otherwise } \\
\text { "0" }\end{array}$ & + \\
\hline
\end{tabular}

Source: Researcher (2013)

\section{Data Presentation and Analysis}

Descriptive Statistics

\begin{tabular}{|l|l|l|l|l|l|l|}
\hline Parameters & Audlag & Audfees & Audfmfr & Audsize & Lcomsize & Yend \\
\hline Mean & 99.68 & 13976.22 & 0.26 & 0.6 & 7.015812 & 0.74 \\
\hline Median & 87 & 9500 & 0 & 1 & 6.973771 & 1 \\
\hline Maximum & 207 & 96000 & 1 & 1 & 8.736253 & 1 \\
\hline Minimum & 39 & 750 & 0 & 0 & 5.76159 & 0 \\
\hline Std. Dev. & 35.6333 & 16231.19 & 0.443087 & 0.494872 & 0.705965 & 0.443087 \\
\hline Jarque-Bera & 18.89453 & 376.6137 & 11.32087 & 8.391204 & 1.004974 & 11.32087 \\
\hline Probability & 0.000079 & 0 & 0.003481 & 0.015062 & 0.605024 & 0.003481 \\
\hline & & & & & & \\
\hline Observations & 50 & 50 & 50 & 50 & 50 & 50 \\
\hline
\end{tabular}

Source: Researchers' computation (2013)

A cursory look at the table above reveals that most companies on the average take more than 90 days to present their financial reports to their shareholders since most of the audit firms engaged spend at least three (3) months before issuing their report. This goes a long way to indicate that financial reporting in Nigeria is indeed not timely. As regards audit firm rotation, it is observed that the mean of approximately $30 \%$ indicate that most companies prefer to hold on to their auditors as against rotating them. This might be as a result of the startup cost associated with changes in audit firms. Furthermore, the mean of audit firm size is indicative of the fact that most companies as observed engage the services of the Big 4. Still from the above table, the average for fiscal year end is about $74 \%$ indicating that most companies observed actually have their fiscal year coinciding with 
the twelve (12) calendar year. Finally, based on the probability of the Jarque Bera statistics, all the variables are normally distributed with the exception of LCOMSIZE whose probability is greater than 0.05 .

Pearson Correlation

\begin{tabular}{|l|l|l|l|l|l|l|}
\hline Parameters & Audlag & Audfees & Audfmfr & Audsize & Lcomsize & Yend \\
\hline AUDLAG & 1 & 0.088955 & -0.165244 & 0.261092 & -0.017518 & -0.001499 \\
\hline AUDFEES & 0.088955 & 1 & -0.190928 & 0.400702 & 0.646072 & 0.16868 \\
\hline AUDFMFR & -0.165244 & -0.190928 & 1 & -0.260603 & -0.167199 & 0.039501 \\
\hline AUDSIZE & 0.261092 & 0.400702 & -0.260603 & 1 & 0.491533 & -0.018615 \\
\hline LCOMSIZE & -0.017518 & 0.646072 & -0.167199 & 0.491533 & 1 & 0.054821 \\
\hline YEND & -0.001499 & 0.16868 & 0.039501 & -0.018615 & 0.054821 & 1 \\
\hline
\end{tabular}

Source: Researchers' computation (2013)

The above table reveals that the amount paid for audit services by a company (AUDFEES) is positively associated with AUDLAG (0.09), AUDSIZE (0.40), LCOMSIZE (0.65) and YEND (0.17) while it has a negative association with AUDFMFR (-0.19). Also, we observe that AUDFMFR has a negative relationship with the other variables except for YEND (0.04). AUDSIZE is observed to have a positive relationship with all other variables observed aside AUDFMFR and YEND that both have a negative relationship of -0.26 and -0.02 respectively. In summary, of all the variables examined, only LCOMSIZE, AUDFEES and AUDSIZE have a fairly strong relationship with each other.

Cochrane-Orcutt Regression Result

\begin{tabular}{|l|l|l|l|l|}
\hline Variable & Coefficient & Std. Error & t-Statistic & Prob. \\
\hline & & & & \\
\hline C & 182.3338 & 65.14592 & 2.798852 & 0.0077 \\
\hline AUDFMFR & -14.6148 & 12.64621 & -1.15567 & 0.2543 \\
\hline LCOMSIZE & -14.2104 & 9.855317 & -1.4419 & 0.1567 \\
\hline AUDFEES & 0.000203 & 0.000429 & 0.472205 & 0.6392 \\
\hline YEND & 6.450711 & 12.25497 & 0.526375 & 0.6014 \\
\hline AUDSIZE & 20.22397 & 12.06275 & 1.676564 & 0.1011 \\
\hline AR(1) & 0.12602 & 0.158068 & 0.797249 & 0.4298 \\
\hline & & & & \\
\hline R-squared & 0.135967 & F-statistic & 1.101545 & \\
\hline Adjusted R-squared & 0.012534 & Prob(F-statistic) & 0.377574 & \\
\hline DW Stat & 1.986443 & & & \\
\hline
\end{tabular}

Source: Researchers' computation (2013)

The regression result after adjusting for autocorrelation as previously revealed by DW statistics shows that all the independent variables jointly explain about $13 \%$ of the systematic variation in the dependent variable (AUDLAG) leaving about $87 \%$ unexplained by factors not captured in the model. However, when adjusted for the degree of freedom, the adjusted " $R$ " reveals that only about $2 \%$ of the systematic variation in the dependent variable can be explained by the independent variables taken together.

On account of the overall significance of the model, the F-statistics and probability of 1.101 and 0.378 respectively indicates that all the independent variables taken holistically does not significantly explain the dependent variable. Hence, the explanatory power of the model is weak.

Based on the individual relationship of the independent variables, the signs of the T-statistics show that AUDFEES, YEND and AUDSIZE all have a positive relationship with AUDLAG while AUDFMFR and LCOMSIZE have a negative relationship.

With respect to the individual significance of the independent variables, the probability values of the Tstatistics reveal that all the variables insignificantly affect AUDLAG at the 0.05 significance level. However, at the 0.1 significance level, only AUDSIZE significantly positively affect AUDLAG while others do not.

In summary, the null hypotheses for research hypotheses 1,3 , and 5 are accepted while the null hypotheses for research hypotheses 2 , and 4 are rejected. 


\section{Diagnostic Tests}

Heteroskedasticity Test: Breusch-Pagan-Godfrey

\begin{tabular}{|l|l|l|l|}
\hline & & & \\
\hline F-statistic & 2.27933 & Prob. F(5,43) & 0.0634 \\
\hline Obs*R-squared & 10.266 & Prob. Chi-Square(5) & 0.068 \\
\hline Scaled explained SS & 10.7544 & Prob. Chi-Square(5) & 0.0565 \\
\hline
\end{tabular}

Source: Researchers' computation (2013)

The Breusch-Pagan-Godfrey Test is use to determine the presence or otherwise of heteroskedasticity which is usually a problem associated with cross-sectional data (Johnson \& Dinardo, 1997). A critical appraisal of the probability values $(0.0634$ and 0.68$)$ indicates the absence of heteroskedasticity as these valves are greater than 0.05 .

Ramsey RESET Test

\begin{tabular}{|l|l|l|l|l|}
\hline & & & & \\
\hline & Value & \multicolumn{1}{|c|}{ Df } & Probability & \\
\hline t-statistic & 0.904604 & 41 & 0.371 & \\
\hline F-statistic & 0.818308 & $(1,41)$ & 0.371 & \\
\hline Likelihood ratio & 0.968346 & 1 & 0.3251 & \\
\hline & & & & \\
\hline
\end{tabular}

Source: Researchers' computation (2013)

The Ramsey Test is use to evaluate the presence of model specification errors of otherwise. From the table, t-statistics and f-statistics values of 0.9046 and 0.8183 with probability values of 0.371 indicates the absence of specification errors as both probabilities are greater than 0.05 . Hence, the use of the OLS technique is in order.

\section{Hypotheses Testing}

The decision rule is to reject the null hypothesis and accept the alternative if the probability value of the t-statistics is less than 0.05 or accept the null and reject the alternative if the probability value is greater than 0.05 .

H1 The rotation of audit firm significantly affect audit report lag (Accept Null).

H2 A positive relationship exists between audit fees and audit report lag (Reject Null)

H3 The size of the company affects the audit report lag (Accept Null).

H4 The type of audit firm has a positive relationship with audit report lag (Reject Null).

H5 Year-end dates significantly affect the audit report lag (Accept Null).

\section{Summary and Conclusion}

The study examined the audit firm rotation and audit report lag in Nigeria. The findings from the study show that there are various factors that could influence the timeliness of the financial reporting. It reveals that audit fees, year -end and audit firm size all have positive relationship with audit report lag. This is consistent with the result obtained in Leventis et al. (2005), it is however inconsistent with the findings of Dyer and Mchugh (1975). The research also establishes that audit firm rotation and company size have a negative insignificant relationship with audit report lag. This result agrees with the findings by Annaert et al., (2002) but disagrees with that of Bamber et al. (1993) and $\mathrm{Ng}$ and Tai (1994).

Based on the above findings, it is recommended for the future that other researchers can examine how ownership structure and government policies or interference will influence the audit report lag as Afify (2009) is of the opinion that audit report lag is expected to decline as the ownership of the client's shares becomes more concentrated.

\section{References}

[1]. Ahmad, R. A. R., \& Kamarudin, K. A. (2003). Audit delay and the timeliness of corporate reporting: Malaysian evidence. Working paper, MARA University of Technology, Shah Alam.

[2]. Ahmed, K. (2003). The timeliness of corporate reporting: a comparative study of South Asia. Advances in International Accounting, $16,17-43$.

[3]. AICPA [American Institute of Certified Public Accountants] (1992). Statement of Position Regarding Mandating Rotation of Audit Firms of Publicly Held Companies. Author. 
[4]. American Accounting Association [AAA] (1954). Accounting and Reporting Standards for Corporate Financial Statement and Preceding Statement and Supplements. Author

[5]. Annaert, J., De Ceuster, M., Polfliet, R., \& Van Campenhout, G. (2002). To be or not to be ... 'too late': The case of the Bel gian semi-annual Earnings announcements. Journal of Business Finance and Accounting, 29(3\&4), 477-495.

[6]. Arrunada, B. \& Paz-Ares, C. (1997). Mandatory rotation of company auditors: A critical examination. International Review of Law and Economics, 17(1), 31-61

[7]. Ashton, R. H., Willingham, J. J., \& Elliott, R. K. (1987). An empirical analysis of audit delay. Journal of Accounting Research, 25(2), 275-292.

[8]. Atiase, R. K., Bamber, L. S., \& Tse, S. (1988). Timeliness of financial reporting, the firm size effect, and stock price reactions to annual earnings announcements. Contemporary Accounting Research, 5(2), 526-552.

[9]. Bamber, E. L. Bamber, M., \& Schoderbek (1993). Audit structure and other determinants of audit report lag: an empirical analy sis. Auditing: A Journal of Practice and Theory 12(1), 1-23.

[10]. Chung, H. (2004). Selective Mandatory Auditor Rotation and Audit Quality: An Empirical Investigation of Auditor Designation Policy in Korea (Doctoral Thesis, Purdue University), West Lafayette, Indiana

[11]. Davies, B., \& Whittred, G. P. (1980). The Association between Selected Corporate Attributes and Timeliness in Corporate Reporting: Further Analysis, 48-60.

[12]. Dopuch N., King, R., \& Schwartz, R. (2001). An experimental investigation of retention and rotation requirements. Journal of Accounting Research, 39(1), 93-117.

[13]. Dyer, J. C., \& McHugh, A. J. (1975). The timeliness of Australian annual report. Journal of Accounting Research, Autumn, $204-$ 219.

[14]. Firth, M., Rui, M. O., \& Wu, X. (2010) Rotate Back or Not After Mandatory Audit Partner Rotation. Hong Kong .

[15]. Francis, J. R. (2004). What do we know about audit quality. The British Accounting Review, 36(4) 345-368.

[16]. Garsanbke, H.P. (1981). The Timeliness of Corporate Financial Disclosure? In Communication Via Annual Report. AFM Explanatory Series? No 11, 204-218.

[17]. Geiger, M. A. \& Raghumandan, K. (2002). Auditor Tenure and Audit Reporting Failures. Auditing: A Journal of Practice and Theory, 21(1), 67-78.

[18]. Ghosha, \& Moon, D. (2002). Auditor Tenure and Perception of Audit Quality. The Accounting Review, 80(2), 585-612.

[19]. Givoly, D., \& Palmon, D. (1982). Timeliness of annual earnings announcements: Some empirical evidence. The Accounting Review, 57(3), 486-508.

[20]. Hakansson, N. (1977). Interim Disclosure and Public Forecast. An Economic Analysis and a Framework for Choice.

[21]. Hamilton, J., Ruddock, C., Stokes, D., \& Taylor, S. (2005). Audit Firm Rotation, Earnings Quality AND Earnings Conservatism.

[22]. Hyeesoo, C. (2004). Selective Mandatory Auditor Rotation \& Audit quality: An empirical investigation of auditor designation policy in Korea (Master's Thesis, Krannert Graduate School of Management Purdue University).

[23]. Jaggi, B., \& Tsui, J. (1999). Determinants of Audit Report Lag: Further Evidence from Hong Kong. Accounting and Business Research, 17-28.

[24]. Johnson, V. E., Khurana, I. K., \& Reynolds, J. K. (2002) Audit-firm tenure and the quality of financial reports. Contemporary Accounting Research, 19(4), 637-660

[25]. Kenley, W. J., \& Staubus, G. J. (1972). Objective and Concept of Financial Statements. Accounting Research Study, 3.

[26]. Kinney, W. R., \& McDaniel, L. S. (1993). Audit Delay for Firms Correcting Quarterly Earnings. Auditing: A Journal of Practice and Theory, 135-142.

[27]. Knechel, W. R., \& Payne, J. L. (2001). Additional Evidence on Audit Report Lag. Auditing: A Journal of Practice and Theory, 137146.

[28]. Leventis, S., Weetman, P., \& Caramanis, C. (2005). Determinants of audit report lag: Some evidence from the Athens Stock Exchange. International Journal of Auditing, 9, 45-58.

[29]. Mansi, S. A., Maxwell, W. F., \& Miller, D. P. (2004). Does Auditor Quality and Tenure Matter to Investors? Evidence from the bond market. Journal of Accounting Research, 42(4), 755-793.

[30]. Michael, G. Steven, S., \& Alan, W. (2003). Journal of Accounting Research, 2003, vol. 41 Issues.

[31]. Nagy, A. (2005). Mandatory audit firm turnover, financial reporting quality, and client bargaining power: the case of Arthur Andersen. Accounting Horizons, 19(2), 51-68.

[32]. Newton, J. D., \& Ashton, R. H. (1989). The Association between Audit Report Technology and Audit Delay. Auditing: A Journal of Practice and Theory, 22-37.

[33]. Onwuchekwa, Erah, D., \& Izedonmi, F. I. (2012). Mandatory Audit Rotation and Audit Independence: Survey of Southern Nigeria, 3.

[34]. Owusu-Ansah, S. (2000). Timeliness of Corporate Financial Reporting in Emerging Capital Markets: Empirical Evidence from Zimbabwe Stock.

[35]. Owusu-Ansah, S., \& Leventis, S. (2006). Timeliness of corporate annual financial reporting in Greece. European Accounting Review, 15, 273-287.

[36]. Penman, S. H. (1984). Timeliness of reporting and the stock price reactions to earnings announcements. Journal of Accounting Research. Spring: 21-47.

[37]. Ruiz-Barbadillo E., \& Gomez-Aguilar N. (2002). Does Auditor Tenure Improve Audit Quality? Mandatory auditor Rotation Versus Long Term Auditing: An empirical analysis. Working paper. University of Cadiz Spain.

[38]. Securities and Exchange Commission (2002). Acceleration of Periodic Report Filing Dates and Disclosure Concerning Website Access to Reports. Retrieved from http://www.sec.gov/rules/final/33-8128.htm.

[39]. Whittred, G. P., Zimmer, I. (1984). Timeliness of financial reporting and financial distress. Account. Rev., 59(2), 287-295.

[40]. Williams, D. D., Dirsmith, M. W. (1988). The effects of audit technology on audit affeciency: Auditing and the timeliness of client earnings announcement. Account. Org. Soc., 13(5), 487-508. 